\title{
The influence of microhabitat on the population dynamics of four herbaceous species in a semiarid area of northeastern Brazil
}

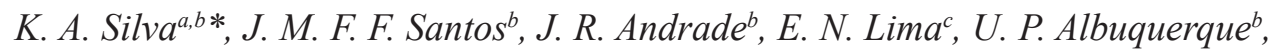 \\ E. M. N. Ferraz ${ }^{d}$ and E. L. Araújo \\ áLaboratório de Biodiversidade, Centro Acadêmico de Vitória, Universidade Federal de Pernambuco - UFPE, \\ Alto do Reservatório, CEP 55608-680, Vitória de Santo Antão, PE, Brazil \\ ${ }^{b}$ Laboratório de Ecologia Vegetal dos Ecossistemas Naturais - LEVEN, Departamento de Biologia, \\ Universidade Federal Rural de Pernambuco - UFRPE, Dois Irmãos, CEP 52171-900, Recife, PE, Brazil \\ 'Universidade Federal do Piauí - UFPI, Campus Cinobelina Elvas, BR 135, Km 3, Planalto Horizonte, \\ CEP 64900-000, Bom Jesus, PI, Brazil \\ dLaboratório Sala Verde, Instituto Federal de Pernambuco - IFPE, Cidade Universitária, \\ CEP 50740-540, Recife, PE, Brazil \\ *e-mail: kleberandradedasilva@hotmail.com
}

Received: May 26, 2014 - Accepted: November 12, 2014 - Distributed: February 29, 2016 (With 4 figures)

\begin{abstract}
Variation in annual rainfall is considered the most important factor influencing population dynamics in dry environments. However, different factors may control population dynamics in different microhabitats. This study recognizes that microhabitat variation may attenuate the influence of climatic seasonality on the population dynamics of herbaceous species in dry forest (Caatinga) areas of Brazil. We evaluated the influence of three microhabitats (flat, rocky and riparian) on the population dynamics of four herbaceous species (Delilia biflora, Commelina obliqua, Phaseolus peduncularis and Euphorbia heterophylla) in a Caatinga (dry forest) fragment at the Experimental Station of the Agronomic Research Institute of Pernambuco in Brazil, over a period of three years. D. biflora, C. obliqua and P. peduncularis were found in all microhabitats, but they were present at low densities in the riparian microhabitat. There was no record of E. heterophylla in the riparian microhabitat. Population size, mortality rates and natality rates varied over time in each microhabitat. This study indicates that different establishment conditions influenced the population size and occurrence of the four species, and it confirms that microhabitat can attenuate the effect of drought stress on mortality during the dry season, but the strength of this attenuator role may vary with time and species.
\end{abstract}

Keywords: demography, density, herb, mortality, natality, spatial variation.

\section{A influência dos microhabitats sobre a dinâmica de populações de quatro espécies herbáceas em uma área semiárida no nordeste do Brasil}

\section{Resumo}

A variação anual na precipitação é considerada o fator mais importante que influencia a dinâmica populacional em ambientes secos. No entanto, diferentes fatores podem controlar a dinâmica populacional em diferentes microhabitats. A hipótese deste estudo é que as variações de microhabitats podem atenuar a influência da sazonalidade climática sobre a dinâmica populacional de espécies herbáceas em uma áreas floresta seca (Caatinga) no Brasil. Então, objetivou-se avaliar a influência de três microhabitats (plano, rochoso e ciliar) sobre a dinâmica das populações de quatro espécies herbáceas (Delilia biflora, Commelina obliqua, Phaseolus peduncularis e Euphorbia heterophylla) em um fragmento de Caatinga da Estação Experimental do Instituto de Pesquisas Agronômicas de Pernambuco, no Brasil, durante um período de três anos. D. biflora, C. obliqua e P. peduncularis foram encontrados em todos os microhabitats, mas elas estavam presentes em baixas densidades no microhabitat ciliar. Não houve registro de E. heterophylla no microhabitat ciliar. O tamanho das populações, as taxas de mortalidade e de natalidade variaram ao longo do tempo em cada microhabitat. Este estudo indica que diferentes as condições de estabelecimento influenciaram o tamanho das populações e a ocorrência das quatro espécies e confirma que microhabitat pode atenuar o efeito do estresse hídrico sobre a mortalidade durante a estação seca, mas a força desse papel atenuador pode variar com o tempo e a espécie considerada.

Palavras-chave: demografia, densidade, erva, mortalidade, natalidade, variação espacial. 


\section{Introduction}

Tropical dry forests represent about $20 \%$ of the world's tropical vegetation and they occur on large areas of the Americas, Africa, Asia and Australia. The vegetation community in these forests growing under strong: 1) climatic seasonality, with a rainy season ranging from three to six months and irregularly distributed in time and space; 2) high evapotranspiration rates and high temperatures (Albuquerque et al., 2012; Menezes et al., 2012; Silva et al., 2013). In addition, the conditions for the establishment of plants in the horizontal space are different which provides high diversity of microhabitats (Santos et al., 2013a).

There are many environmental factors that can affect the population sizes of herbaceous species in dry habitats (Forbis et al., 2004; Nippert et al., 2006; Silva et al., 2011; Souza et al., 2014), but the variation of annual rainfall is the most important and most discussed factor in the literature (Flores-Torres and Montaña, 2012; Nippert et al., 2006; Santos et al., 2013b; Volis et al., 2004; Wang, 2005). However, microhabitat types are quite diverse in dry habitats, and such diversity may allow different factors to determine and modulate population dynamics (Forbis et al., 2004; García-Cháves et al., 2014; Miller and Duncan, 2003; Vega and Montaña, 2004; Wang, 2005). For instance, in dry habitat areas that receive the same amount of rainfall, variation in establishment conditions for plants on a small spatial scale may alter the regenerative dynamics of populations, as reported in a few studies: (1) The biomass of herbaceous populations in a semiarid savanna region in central Kenya is larger at the ridge and upper hillslope microhabitats a mountain than in the lower hillslope and lowlands (Augustine, 2003); (2) Agropyron cristatum, which occurs in steppe and dune microhabitats in the Hunshandake Desert of North China, was more abundant in the steppe sites because steppe soils can store more water and are richer in nutrients (Wang, 2005); and (3) Microhabitats created by rodent action in a semiarid region in southern Colorado exhibited higher temperatures and lower humidity and, as a result, reduced seedling survival of herbaceous species when compared with undisturbed microhabitats (Forbis et al., 2004).

In Brazil, dry habitats are well represented in Caatinga vegetation, which covers over $50 \%$ of the Northeast region (Andrade-Lima, 1981; Araújo et al., 2007). Caatinga vegetation grows in semiarid climates, with rainy and dry season well-defined and annual rainfall ranging from 252 to $1200 \mathrm{~mm}$, but with average less than $600 \mathrm{~mm}$. The total annual rainfall is unevenly distributed between the seasons and approximately $85 \%$ of the annual precipitation occurs during the rainy season. The rainy season can vary from three to six months depending on locality. Plant diversity is high in the Caatinga, and herbaceous species account for most of the diversity. During the long dry season, most species lose leaves (woody species) or die (therophyte herbaceous) (Araújo et al., 2007; Sampaio, 1995). However, during the dry season, it is common to find small patches with a few individuals of different species with leaves (woody species) or live (therophyte herbaceous). These patches might indicate variation in microhabitat conditions that allow species to survive, including therophytes. Such variation may be represented by inclines, declines, flooded areas or, in most cases, intermittent rivers. There is also diversity in soil types, as soils may be shallow, compact, eroded, poorly infiltrated, deep, sandy and, often, represented by rocky outcrops. Some variation is natural, but some is the result of anthropogenic actions made about the management of space and resources in the Caatinga (Albuquerque et al., 2012; Andrade-Lima, 1981; Araújo et al., 2007; Sampaio, 1995).

Based on the assumption that small-scale variation in the establishment conditions for plants may alter the regenerative dynamics of herbaceous populations in dry habitats, we hypothesized that microhabitat variation in the Caatinga may reduce the influence of climatic seasonality on the population dynamics of herbaceous species. We expect that differences in microhabitat conditions may produce spatiotemporal variation in population size (density). If in this study no significant difference in population size is found between microhabitat conditions, then the mitigating role of spatial heterogeneity in the Caatinga must be reexamined. Therefore, we sought to describe the dynamics of four herbaceous populations in different microhabitat conditions and to evaluate the influence of microhabitat on the density, natality and mortality rates of these four species in the Caatinga.

\section{Material and Methods}

\subsection{Study area}

The study was conducted in a Caatinga (dry forest) fragment at the Experimental Station of the Agronomic Research Institute of Pernambuco - IPA ( $8^{\circ} 14^{\prime} 18^{\prime \prime} \mathrm{S}$ and $35^{\circ} 55^{\prime} 20^{\prime}$ ' W, $535 \mathrm{~m}$ a.s.l.) in Caruaru, Pernambuco State, Brazil (Figure 1). The Station maintains an area of native vegetation where human activities and animal grazing are not allowed. This area is considered preserved.

The climate is seasonal, with an average annual rainfall of $680 \mathrm{~mm}$ and absolute minimum and maximum temperatures of $11^{\circ} \mathrm{C}$ and $38^{\circ} \mathrm{C}$, respectively. The rainy season usually lasts from March to August. However, there is great variation in the total annual rainfall, and the rainy season may begin in February or end in September. In addition, there may be dry periods in the rainy season and erratic rainfall during the dry season. In our study, erratic rainfall (rainfall during the dry season) was recorded in December 2005 and January 2008 (Figure 2). Monthly rainfall data (Figure 2) were collected at the Experimental Station. Climatic seasonality determined the deciduousness of the woody flora in the dry season and it controlled the emergence of most herbs in the rainy season.

Soils in this area are eutrophic yellow podzolic, and the area is drained by the Olaria creek, a tributary of the Ipojuca river (Alcoforado-Filho et al., 2003; Araújo et al., 2005; Reis et al., 2006; Silva et al., 2008). The woody component of the study area vegetation is rich in Leguminosae and 


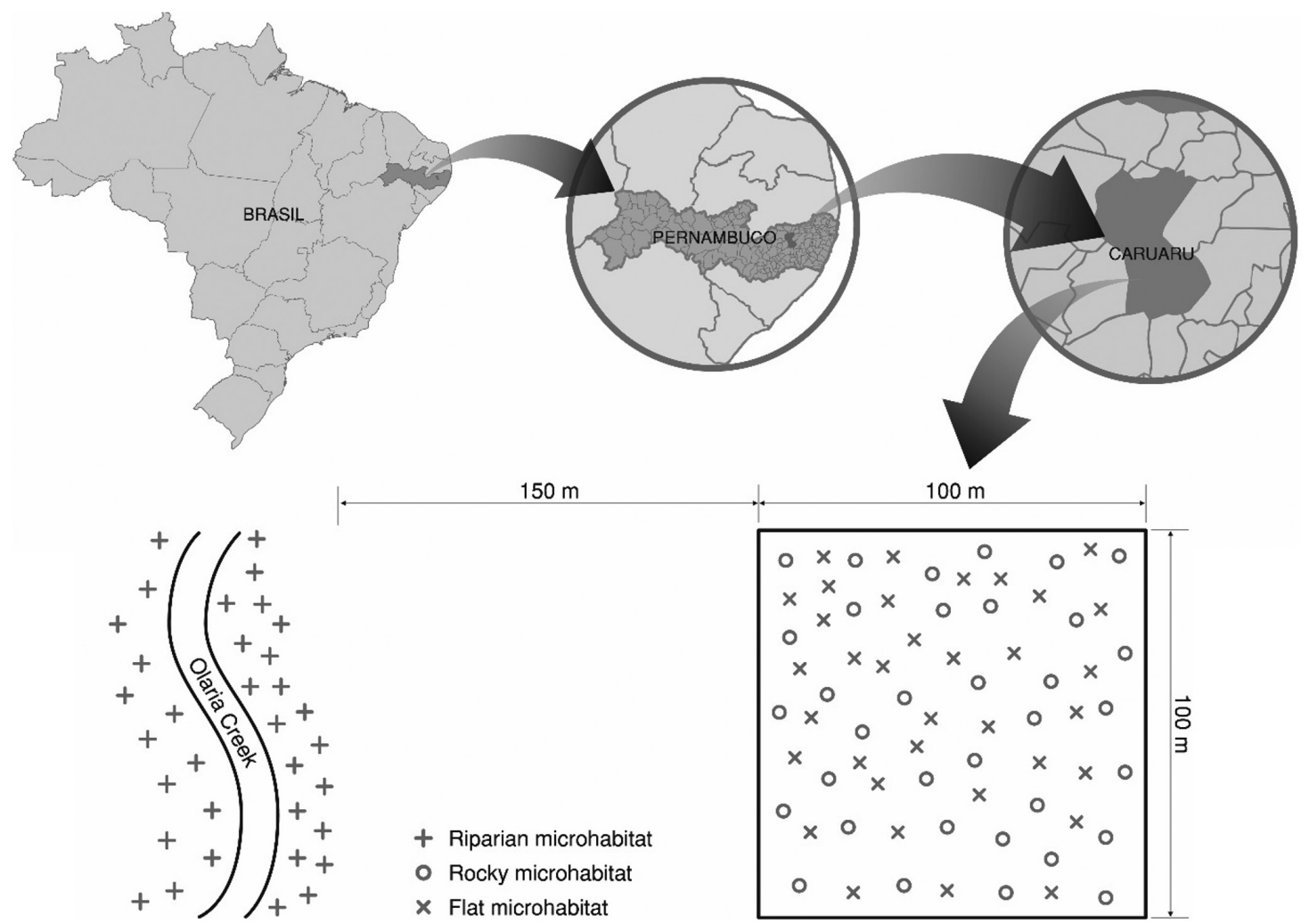

Figure 1. Localization of the study area (Experimental Station of the Agronomic Research Institute of Pernambuco - IPA in Caruaru, Pernambuco State, Brazil) and experimental design.

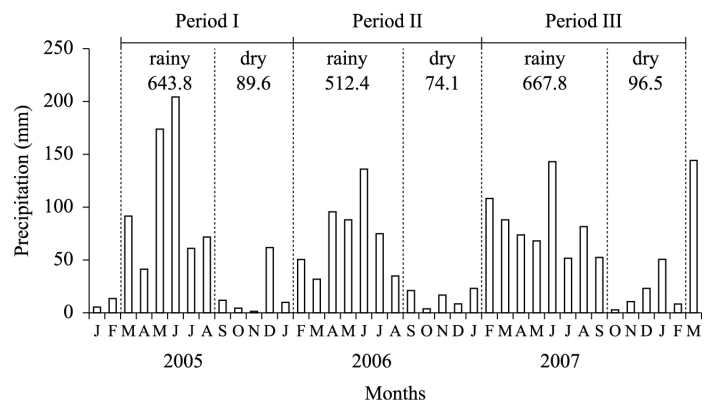

Figure 2. Monthly precipitation and total precipitation during the rainy and dry season for three period. Data provided by the meteorological station of Empresa Pernambucana de Pesquisa Agropecuária (IPA) - Caruaru, Pernambuco, Brazil

Euphorbiaceae species (Alcoforado-Filho et al., 2003), while the herbaceous component is rich in Malvaceae, Poaceae, Asteraceae, Euphorbiaceae and Convolvulaceae species (Araújo et al., 2005; Reis et al., 2006).

\subsection{Selected species}

In general, herbaceous component performs an important role in the maintenance and restoring biodiversity, by interfering with the recruitment of seedlings, be an additional source of food for fauna (providing pollen, nectar and resin) and assist in the retention of seeds in the topsoil through intertwining their roots (Santos et al., 2013b). Therefore, understanding the dynamics of herbaceous species generates information that can be accessed in future proposals for recovery of disturbed areas.

The annual herbaceous species selected for the study were Delilia biflora (L.) Kuntze (Asteraceae), Commelina obliqua Vahl (Commelinaceae) and Phaseolus peduncularis W.P.C. Barton (Fabaceae), which are part of the permanent flora, and Euphorbia heterophylla (L.) Klotzsch and Garcke (Euphorbiaceae), which is likely part of the transient flora and forms large populations in the Experimental Station of IPA (Araújo et al., 2005; Reis et al., 2006).

The four species are land plants and reach heights ranging between 20 and $40 \mathrm{~cm}$. Studies on the vegetation of the study area show that D. biflora and C. obliqua had a preference for rocky microhabitat. The preference was given based on the size of the population in each microhabitat (Araújo et al., 2005; Reis et al., 2006).

\subsection{Sampling of populations}

In the native vegetation area at the Experimental Station of IPA, there is a 1 ha sampling site $150 \mathrm{~m}$ from the Olaria creek margin where studies on the vegetation (woody) have been conducted. At this sampling site, we recognized three microhabitats: riparian, flat and rocky (Figure 1). The flat microhabitat corresponds to reasonably flat terrain, with well-formed soils and no major elevation 
gain. Moreover, woody plants of that microhabitat have an average height of $5 \mathrm{~m}$, but form a more open canopy with greater sunlight penetration compared to the riparian microhabitat, and this promotes rapid drying of soil in the dry season. The rocky microhabitat corresponds to small rocky outcrops ranging from $2 \mathrm{~m}^{2}$ to $5 \mathrm{~m}^{2}$ in area and $0.1 \mathrm{~m}$ to $1 \mathrm{~m}$ in height. The rocky microhabitat occurs as distinct scattered outcrops in the flat microhabitat, some well-shaded by canopies of woody plants (average height of $5 \mathrm{~m}$ ) and others more exposed to the sunlight. In addition to these two microhabitats, there is a riparian microhabitat on the banks of the Olaria creek, with vegetation growing on terrain with a gentle slope that is not subject to flooding, despite being riparian (Araújo et al., 2005; Reis et al., 2006; Santos et al., 2013a; Silva et al., 2008). Because it is a riparian environment, the moisture content in the soil tends to be higher, favoring the occurrence of larger woody plants (woody plants are on average $7 \mathrm{~m}$ tall and form a relatively closed canopy) that retain their foliage for longer periods than woody plants in the flat and rocky microhabitats, resulting in greater shading (Araújo et al., 2005; Santos et al., 2013a).

The habitat of Caatinga vegetation in the Experimental Station of IPA features 30 ha of size. In this habitat, the flat, rocky and riparian microhabitats, approximately corresponds to $45 \%, 40 \%$ and $15 \%$, respectively (Araújo et al., 2005; Reis et al., 2006). In each of the three microhabitats, we randomly allocated 35 plot of $1 \mathrm{~m} \times 1 \mathrm{~m}$ of size (Figure 1 ).

We counted and marked all individuals from the four species inside each plot. To mark individuals, we used plastic labels tied to the plants with metal wire (covered with plastic). We considered plants with no connections to other plants at the soil level to be distinct individuals, and we collected their reproductive material for taxonomic identification. We monitored the plots monthly and counted the number of births and deaths. We considered birth the emission of seedling aboveground. We considered dead all individuals that showed a complete loss of aerial parts or that fell completely dry to the ground. The study was conducted from March 2005 to March 2008, and the observation time was divided into three periods (an 11-month period, a 12-month period and a 13-month period), each with a dry season and a rainy season, for a total of three years of monitoring. Each period had no exactly 12 months due to anticipation and/or extension of the rainy season in the second and third period (Figure 1).

\subsection{Data analysis}

The botanical material was herbalized according to typical preparation, drying and mounting techniques used for voucher herbarium specimens (Mori et al., 1989). Taxonomic identification was carried by comparison with voucher specimens deposited in the herbariums of Prof. Vasconcelos Sobrinho (PEUFR) of the Federal Rural University of Pernambuco and Dárdano de Andrade Lima of the Agronomic Research Institute (IPA), and other experts provided additional help.
We calculated monthly rates of population increase ( $r$, instantaneous rate of increase), as well as natality ( $b$, number of plants germinated in a given month) and mortality ( $d$, number of deaths in a given month) rates. Rates were calculated according to the following equations: 1. $r=\ln \left[\left(\mathrm{N}_{0}+\mathrm{B}-\mathrm{D}\right) \cdot \mathrm{N}_{0}^{-1}\right] \cdot \mathrm{T}^{-1} ; 2 \cdot d=\ln \left[\left(\mathrm{N}_{0}+\mathrm{D}\right)\right.$. $\left.\mathrm{N}_{0}^{-1}\right] \cdot \mathrm{T}^{-1} ; 3 . b=\ln \left[\left(\left[\left(\mathrm{N}_{0}+\mathrm{B}\right) \cdot \mathrm{N}_{0}^{-1}\right] \cdot \mathrm{T}^{-1}\right.\right.$; where $N_{0}$ is the number of individuals in the population according to the initial census; $B$ is the number of individuals born in the interval between two subsequent observations; $D$ is the number of individuals who died in the interval between two subsequent observations; and $T$ is time (number of days between two subsequent observations) (Condit et al., 1996; Swaine and Lieberman, 1987). Differences in density between rain and dry seasons of each microhabitat per period, differences in total density (rain + dry) between microhabitats per period and differences in total density (rain + dry) between periods of each microhabitat were identified with the Kruskal-Wallis test (Zar, 1996) in the software package BioEstat 2.0.

\section{Results}

\subsection{Microhabitats vs. density}

Populations of Delilia biflora, Commelina obliqua and Phaseolus peduncularis occurred in all three microhabitats, whereas Euphorbia heterophylla only occurred in the flat and rocky microhabitats (Table 1; Figure 3). Considering the total density (rain + dry), in the three periods, the population of $D$. biflora was significantly larger in the flat and rocky microhabitats, and that of C. obliqua was larger in the rocky one. E. heterophylla formed the larger population in the rocky microhabitat during the first period. For $P$. peduncularis, the population density was significantly higher in the rocky microhabitat only during the second period. The densities of $D$. biflora, C. obliqua and $P$. peduncularis were lower in the riparian microhabitat (Table 1).

Considering the total density (rain + dry), there was a significant and drastic reduction in the population sizes of D. biflora, E. heterophylla and $P$. peduncularis in the flat and rocky microhabitats in the second and third periods (Table 1; Figure 3). Although few individuals occurred in the riparian microhabitat, the size of the D. biflora population increased in the second period, and it increased significantly in the third period (Table 1; Figure 3). The density of $P$. peduncularis in the riparian microhabitat was significantly higher in the second and third periods (Table 1; Figure 3). On average, the population size of C. obliqua in the flat microhabitat was similar for the three periods, but it decreased significantly in the second and third periods in the rocky microhabitat. In the riparian microhabitat, the number of individuals was low, and the population disappeared in the second period (Table 1; Figure 3).

The population size of E. heterophylla and P. peduncularis in the flat and rocky microhabitats was higher in the rainy season for all three periods. In the second period, the 
Table 1. Densities mean and standard deviations of four herbaceous populations in different microhabitats, and periods $(\mathrm{P})$ and seasons of a semiarid area in northeastern Brazil.

\begin{tabular}{|c|c|c|c|c|c|c|c|c|c|c|}
\hline \multirow{2}{*}{ Species } & & \multicolumn{2}{|c|}{ Flat } & \multicolumn{2}{|c|}{ Rocky } & \multicolumn{2}{|c|}{ Riparian } & \multirow[t]{2}{*}{ Flat } & \multirow{2}{*}{$\begin{array}{l}\text { Rocky } \\
\text { Total } \\
\end{array}$} & \multirow[t]{2}{*}{ Riparian } \\
\hline & & Rain & Dry & Rain & Dry & Rain & Dry & & & \\
\hline \multirow{3}{*}{ D. biflora } & $\mathrm{I}$ & $5032 \pm 788 \mathrm{a}$ & $1865 \pm 1092 \mathrm{~b}$ & $3228 \pm 564 a$ & $1457 \pm 534 \mathrm{~b}$ & $2 \pm 1 \mathrm{a}$ & $3 \pm 4 a$ & $3592 \pm 1877 \mathrm{aA}$ & $2423 \pm 1062 \mathrm{aA}$ & $2.54 \pm 2.69 \mathrm{bB}$ \\
\hline & II & $118 \pm 16 \mathrm{a}$ & $101 \pm 4 a$ & $212 \pm 63 \mathrm{a}$ & $43 \pm 36 b$ & $5 \pm 1 \mathrm{a}$ & $4 \pm 0 \mathrm{a}$ & $111 \pm 15 \mathrm{aB}$ & $141 \pm 101 \mathrm{aB}$ & $4.33 \pm 0.88 \mathrm{bB}$ \\
\hline & III & $382 \pm 112 \mathrm{a}$ & $153 \pm 128 b$ & $192 \pm 53 \mathrm{a}$ & $112 \pm 12 b$ & $7 \pm 1 \mathrm{a}$ & $6 \pm 1 \mathrm{a}$ & $294 \pm 162 \mathrm{aB}$ & $161 \pm 58 \mathrm{aB}$ & $6.46 \pm 0.87 \mathrm{bA}$ \\
\hline \multirow{3}{*}{ C. obliqua } & $\mathrm{I}$ & $36 \pm 5 \mathrm{a}$ & $19 \pm 9 \mathrm{~b}$ & $87 \pm 16 \mathrm{a}$ & $60 \pm 14 \mathrm{~b}$ & $1 \pm 0 \mathrm{a}$ & $0.6 \pm 0.5 \mathrm{a}$ & $28 \pm 11 \mathrm{bA}$ & $75 \pm 20 \mathrm{aA}$ & $0.81 \pm 0.40 \mathrm{cA}$ \\
\hline & II & $23 \pm 9 \mathrm{a}$ & $18 \pm 7 \mathrm{a}$ & $54 \pm 6 a$ & $33 \pm 8 \mathrm{a}$ & - & - & $21 \pm 9 \mathrm{bA}$ & $45 \pm 13 \mathrm{aB}$ & - \\
\hline & III & $26 \pm 3 a$ & $10 \pm 3 \mathrm{~b}$ & $53 \pm 6 \mathrm{a}$ & $34 \pm 3 b$ & $2 \pm 1 \mathrm{a}$ & $1.2 \pm 0.44 \mathrm{a}$ & $19 \pm 9 \mathrm{bA}$ & $46 \pm 11 \mathrm{aB}$ & $1.46 \pm 0.87 \mathrm{cA}$ \\
\hline \multirow{3}{*}{ E. heterophylla } & $\mathrm{I}$ & $47 \pm 10 \mathrm{a}$ & $25 \pm 14 \mathrm{~b}$ & $111 \pm 19 a$ & $47 \pm 25 b$ & - & - & $37 \pm 16 \mathrm{bA}$ & $82 \pm 39 \mathrm{aA}$ & - \\
\hline & II & $7 \pm 1 \mathrm{a}$ & $5 \pm 2 b$ & $14 \pm 2 \mathrm{a}$ & $4 \pm 3 b$ & - & - & $6 \pm 2 \mathrm{aC}$ & $10 \pm 6 \mathrm{aC}$ & - \\
\hline & III & $30 \pm 15 \mathrm{a}$ & $4 \pm 2 b$ & $25 \pm 7 \mathrm{a}$ & $16 \pm 2 b$ & - & - & $20 \pm 17 \mathrm{aB}$ & $21 \pm 7 \mathrm{aB}$ & - \\
\hline \multirow{3}{*}{ P. peduncularis } & $\mathrm{I}$ & $995 \pm 109 a$ & $528 \pm 207 \mathrm{~b}$ & $1091 \pm 154 \mathrm{a}$ & $473 \pm 137 b$ & $6 \pm 2 \mathrm{a}$ & $9 \pm 2 \mathrm{a}$ & $783 \pm 288 \mathrm{aA}$ & $810 \pm 351 \mathrm{aA}$ & $7.54 \pm 2.46 \mathrm{bC}$ \\
\hline & II & $73 \pm 21 \mathrm{a}$ & $59 \pm 1 \mathrm{~b}$ & $140 \pm 46 \mathrm{a}$ & $90 \pm 11 \mathrm{~b}$ & $14 \pm 2 b$ & $20 \pm 2 \mathrm{a}$ & $67 \pm 17 \mathrm{bC}$ & $119 \pm 43 \mathrm{aB}$ & $17 \pm 4 \mathrm{cB}$ \\
\hline & III & $133 \pm 36 a$ & $77 \pm 28 \mathrm{~b}$ & $166 \pm 31 \mathrm{a}$ & $111 \pm 13 b$ & $24 \pm 0.5 \mathrm{a}$ & $23 \pm 0.4 \mathrm{~b}$ & $112 \pm 43 \mathrm{aB}$ & $145 \pm 37 \mathrm{aB}$ & $24 \pm 1 \mathrm{bA}$ \\
\hline
\end{tabular}

The same lower case letters in a line (between seasons of each microhabitat and between microhabitats) and the same capital letters in a column (between periods of each microhabitat of each species) indicate a lack of significant differences $(\mathrm{P}<0.05)$ based on the Kruskal-Wallis analysis of variance.

number of individuals of $C$. obliqua was similar from season to season in the flat microhabitat. The size of the C. obliqua population in the riparian microhabitat was similar between seasons. For D. biflora, the number of individuals remained constant in the flat (second period) and riparian (all three periods) microhabitats (Table 1; Figure 3). The size of the $P$. peduncularis population in the riparian microhabitat was higher in the dry season of the second period and in the rainy season of the third period (Table 1; Figure 3).

The populations of the four species increased during the rainy season of all three periods in the flat and rocky microhabitats. In the riparian microhabitat, population peaks in the rainy season varied between periods for D. biflora, C. obliqua and P. peduncularis (Figure 3). The amount by which the population increased during the dry season varied between periods and microhabitats for the four species (Figure 3).

There was a decrease in population size in the flat and rocky microhabitats in most months, and the increase was not significant in the riparian microhabitat (Figure 3). Population decrease for the four species varied between microhabitats and seasons (Figure 3).

\subsection{Microhabitats vs. natality and mortality}

We recorded births in rainy seasons of all three periods in the flat and rocky microhabitats. In the riparian microhabitat, seedling recruitment for $D$. biflora, C. obliqua and P. peduncularis in the rainy seasons varied between periods (Figure 4). Seedling recruitment in the dry seasons varied between microhabitats for the four species (Figure 4). We recorded the highest natality rates for D. biflora and P. peduncularis in December 2005, in the riparian and flat microhabitats, respectively. The highest natality rates for C. obliqua were recorded in April 2007 in the riparian microhabitat, and for E. heterophylla, the highest natality occurred in February 2007 in the rocky microhabitat (Figure 4).
We recorded deaths in the flat and rocky microhabitats during the rainy and dry seasons of all three periods for the four species studied (Figure 4). In the riparian microhabitat, the mortality rates for D. biflora, C. obliqua and $P$. peduncularis varied between periods in the rainy and dry seasons. The highest mortality rates for the four species were recorded in December 2005 in the flat microhabitat (Figure 4).

\section{Discussion}

\subsection{Microhabitats vs. density}

Studies of the population dynamics of herbaceous species in dry (Miller and Duncan, 2003; Santos et al., 2013b; Vega and Montaña, 2004; Volis et al., 2004; Wang, 2005) and wet forests (Baeten et al., 2009; Flores-Torres and Montaña, 2012; Kolb et al., 2007; Pino et al., 2007; Suzuki et al., 2003;) around the world have shown that heterogeneity in establishment conditions (microhabitats) for seedlings may limit population sizes and occurrence. This phenomenon was observed for some herbaceous populations in the dry forest (Caatinga) of Brazil (Andrade et al., 2007; Araújo et al., 2005; Lima et al., 2007; Reis et al., 2006; Santos et al., 2012; Silva et al., 2008), and it was also observed in this study.

In the same plots sampled in our study, Araújo et al. (2005) found that some herbaceous species showed preferences for specific microhabitat conditions. D. biflora and C. obliqua, for instance, formed larger populations in patches with rocky outcrops. However, year-to-year variation in density was observed for monitored populations, indicating that species preferences for specific microhabitats may vary over time. This suggests that microhabitat features may also vary, and this led us to question about what particular features might be important for this variation. For example, microhabitats that receive the same amount of rainfall may differ in water retention capacity (Forbis et al., 2004; 

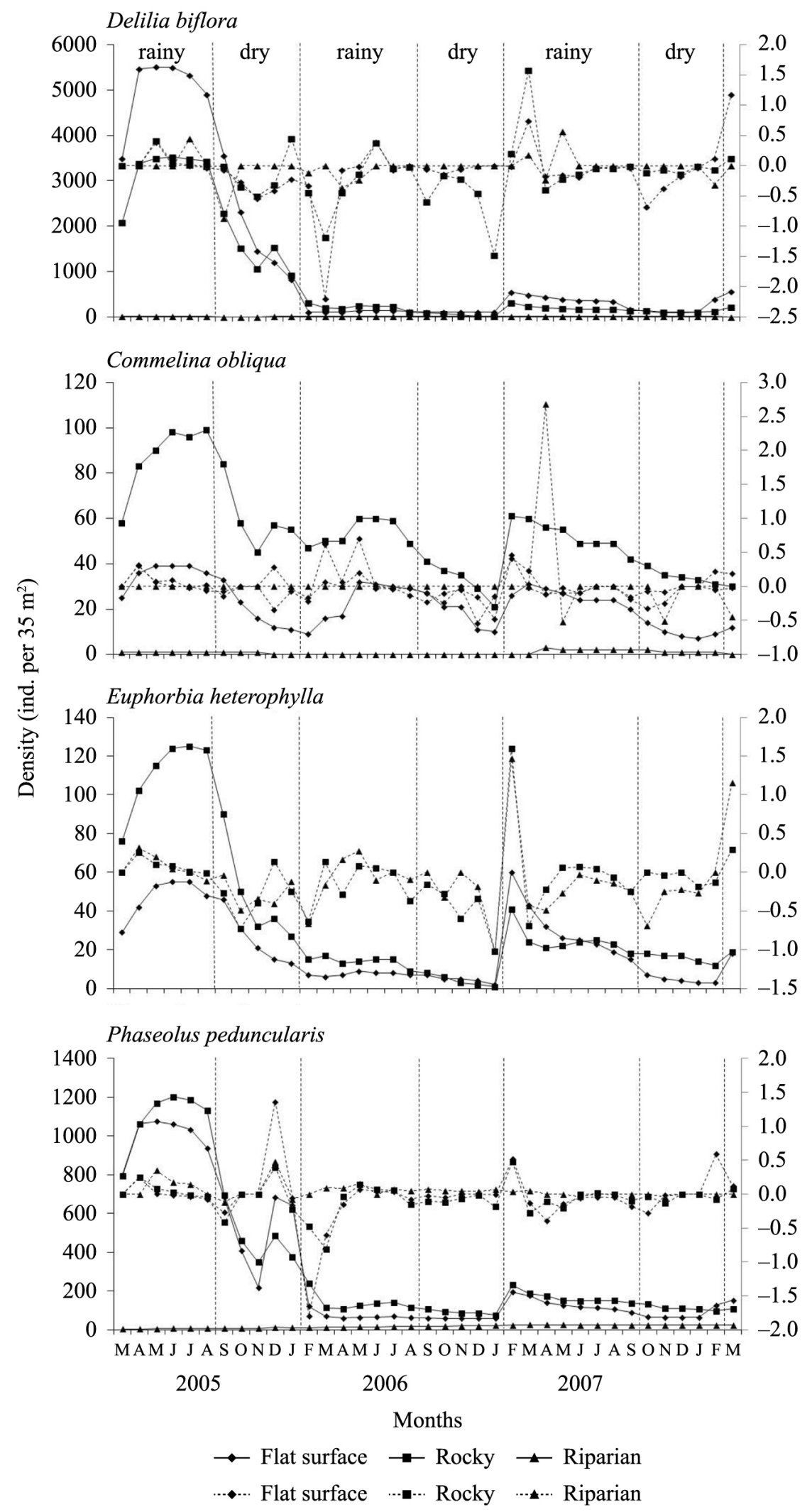

Figure 3. Monthly density (solid line) and monthly rates of population increase (dashed line) of four herbaceous species at the 35 plots of flat, rocky and riparian microhabitats of a semiarid area in northeastern Brazil. 

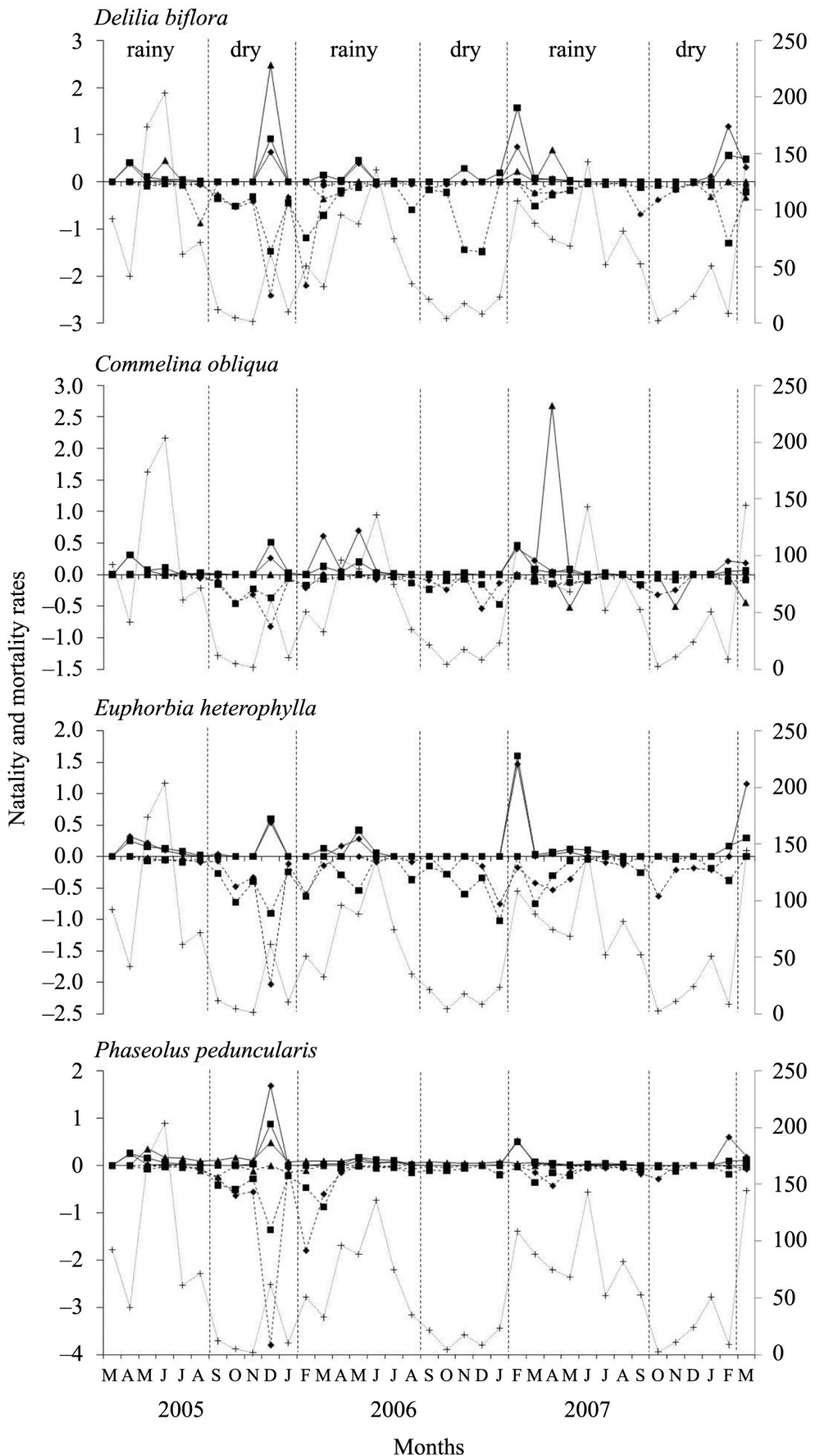

$$
\begin{aligned}
& \rightarrow \text { Flat surface } \rightarrow \text { Rocky } \rightarrow \text { Riparian } \rightarrow \text { - Precipitation } \\
& \cdots \bullet \text { Flat surface } \cdots \cdots \text { Rocky } \cdots \cdots \text { Riparian }
\end{aligned}
$$

Figure 4. Precipitation, and monthly natality (solid line) and mortality (dashed line) rates of four herbaceous species at the 35 plots of flat, rocky and riparian microhabitats of a semiarid area in northeastern Brazil. 
García-Cháves et al., 2014; Vega and Montaña, 2004; Wang, 2005).

In rocky outcrops that occur within forested areas, the occurrence of a moss layer and sediment accumulation in rocky outcrop crevices are sufficient to provide a substrate and promote the development of a dense layer of herbaceous plants during the growing season, when temperature and humidity conditions are favorable for seedling recruitment, establishment and survival (Araújo et al., 2005; Nordbakken et al., 2004; Silva et al., 2008; Suzuki et al., 2003). Water accumulation in rocky outcrop crevices may explain the high density of individuals of the four species in the rocky microhabitat, especially $C$. obliqua, which has a preference for this microhabitat. In addition, rocky outcrops were important in maintaining the population density of $P$. peduncularis in the driest year, and this has also been observed for other herbaceous species in the Caatinga (Lima et al., 2007). In the riparian microhabitat, the low population densities of D. biflora, C. obliqua and $P$. peduncularis may be explained by: (1) shading from the canopy of woody species. This relationship is similar to what has been reported for other herbaceous species whose population size decreases with increased shading (Araújo et al., 2005; Kolb et al., 2007; Silva et al., 2009); (2) higher recruitment of seedlings of species of shrubs and trees. Therefore, the plots of riparian microhabitat were not less bare when compared to the other microhabitats. The intraspecific and interspecific competition for water and/or space reduces the size of herbaceous populations (Leger et al., 2014; Sletvold, 2005; Thomson, 2005).

Seasonal and inter-annual variation in rainfall totals have in fact been identified as predictors of population size for herbaceous species in arid and semiarid ecosystems (Nippert et al., 2006; Volis et al., 2004). The density of herbaceous plants is sharply reduced as a result of a decrease in total rainfall between successive seasons and years (Andrade et al., 2007; Nippert et al., 2006; Silva et al., 2008; Volis et al., 2004). However, small-scale variation in the establishment conditions for seedlings may reduce the impact of seasonal and inter-annual variation on rainfall totals and population size for some species (Silva et al., 2008; Vega and Montaña, 2004; Wang, 2005), indicating that predictive models about the role of climatic seasonality in the population dynamics of herbaceous plants in the Caatinga must take into account the importance of microhabitats. Microhabitats may act as temporary refuges for maintaining biological diversity in dry habitats.

\subsection{Microhabitats vs. natality and mortality}

In tropical dry forests, the germination of herbaceous species is concentrated in the rainy season (Nippert et al., 2006; Price and Morgan, 2007; Thomson, 2005), but seedling recruitment in the rainy season may vary between microhabitats (Miller and Duncan, 2003; Vega and Montaña, 2004; Volis et al., 2004; Wang, 2005). In some dry forests, microhabitats that receive the same amount of rainfall may differ in water retention capacity despite their proximity, with those having greater capacity being the most favorable to seedling establishment (Forbis et al., 2004; Vega and Montaña, 2004; Wang, 2005).

Studies of the population dynamics of herbaceous species in the semiarid areas of Brazil (Caatinga) have also indicated that variation in establishment conditions for seedlings may promote natality in some populations (Andrade et al., 2007; Lima et al., 2007; Santos et al., 2012; Silva et al., 2008). In our study, natality rates for the four species in the rainy seasons followed the same pattern of birth synchronization recorded in other dry habitats. In addition, variation in natality peaks between microhabitats during the rainy seasons showed that different microhabitat conditions may promote seedling recruitment in the Caatinga, but this may vary over time.

In arid and semiarid ecosystems, the occurrence of isolated rainfall in the dry season has been shown to be a stressor of community dynamics because it induces off-season seed germination, which is followed by seedling death (Araújo et al., 2005, 2007; Lima et al., 2007; Salo, 2004; Silva et al., 2008). Nevertheless, in addition to the influence of erratic rains, natality rates recorded in the dry season are related to both the occurrence of microhabitats located near water bodies, which provide more favorable humidity conditions (Lima et al., 2007), and the availability of microhabitats with a greater capacity to store water (Forbis et al., 2004; Vega and Montaña, 2004; Wang, 2005). In our study, natality rates recorded in the dry seasons of each microhabitat were due to erratic rains in the area, but the death rate of recruited seedlings was higher in the flat microhabitat for populations of D. biflora and P. peduncularis, supporting the hypothesis that the microhabitat type may actually affect population persistence in dry habitats.

In general, mortality in the rainy season is less influenced by microhabitat heterogeneity than intraspecific (Gustafsson and Ehrlén, 2003; Nordbakken et al., 2004; Sletvold, 2005; Suzuki et al., 2003) and interspecific (Miller and Duncan, 2003; Nordbakken et al., 2004; Thomson, 2005) competition for water and/or space. Nevertheless, at the end of the rainy season and during the dry season, microhabitats with greater water retention capacity and microhabitats closer to water bodies can minimize the impact of water stress on plant survival (Forbis et al., 2004; Silva et al., 2008; Suzuki et al., 2003; Wang, 2005).

Mortality rates recorded in this study for the four populations in the rainy season were mostly determined by the occurrence of rain. The impact of rain on juvenile plants weakened by drought or recently germinated seedlings (Santos et al., 2012) may cause them to die. In the drier year, the peak mortality rates for D. biflora, E. heterophylla and $P$. peduncularis occurred during the dry season in the rocky microhabitat, while for $C$. obliqua the highest mortality occurred in the flat microhabitat. In contrast, in wetter years, the peak mortality rates for D. biflora were recorded in the flat and rocky microhabitats. For C. obliqua, they were observed in the flat and riparian microhabitats, and for E. heterophylla and P. peduncularis, peak mortality rates were only observed in the flat microhabitat. 
This study showed that microhabitats may actually attenuate the impact of dry season water stress on the mortality rates of herbaceous species, but the strength of this attenuator role may vary with time and species. Considering the microhabitat and the climatic seasonality, microhabitat type (i.e., flat, rocky or riparian) might not be the only factor mediating the stress experienced by plants. There may be some other factor not measured in this study that is modifying habitat conditions from year to year. Therefore, the question remains: which microhabitat variables affect the favorability of plant establishment conditions from year to year in dry habitats? If species type is important, which physiological plant traits are the determinants for the specie remain in the microhabitat?

It is widely recognized that species diversity is usually lower in dry habitats than in humid ones, largely because of the more restrictive conditions for plant development in dry habitats. Therefore, we suggest that the mitigating role of microhabitats in maintaining local diversity should be taken into account by conservation programs attempting to maintain plant diversity in such environments.

\section{Acknowledgements}

The authors thank CNPq for financial support (478521/2001-4; 478087/2004-7; 471805/2007-6; 301147/2003-3; $303544 / 2007-4$ ) and for granting a PhD scholarship and the Experimental Station of the Agricultural Research Institute of Pernambuco - IPA and the Federal Rural University of Pernambuco (UFRPE) for logistical support. We also thank the researchers at the Laboratory of Plant Ecology of Northeastern Ecosystems (LEVEN-UFRPE) for help with data collection and processing.

\section{References}

ALBUQUERQUE, U.P., ARAÚJO, E.L., ASFORA-ELDEIR, A.C., LIMA, A.L.A., SOUTO, A., BEZERRA, B.M., FERRAZ, E.M.N., FREIRE, E.M.X., SAMPAIO, E.V.S.B., LAS-CASAS, F.M.G., MOURA, G.J.B., PEREIRA, G.A., MELO, J.G., RAMOS, M.A., RODAL, M.J.N., SCHIEL, N., LYRA-NEVES, R.M., ALVES, R.R.N., AZEVEDO-JUNIOR, S.M., TELINO JUNIOR, W.R. and SEVERI, W., 2012. Caatinga revisited: ecology and conservation of an important seasonal dry forest. The Scientific World Journal, vol. 2012, pp. 1-18. http://dx.doi.org/10.1100/2012/205182. PMid:22919296.

ALCOFORADO-FILHO, F.G., SAMPAIO, E.V.S.B. and RODAL, M.J.N., 2003. Florística e fitossociologia de um remanescente de vegetação caducifólia espinhosa arbórea em Caruaru. Acta Botanica Brasílica, vol. 17, no. 2, pp. 287-303. http://dx.doi. org/10.1590/S0102-33062003000200011.

ANDRADE, J.R., SANTOS, J.M.F.F., LIMA, E.M., LOPES, C.G.R., SILVA, K.A. and ARAÚJO, E.L., 2007. Estudo populacional de Panicum trichoides Swart. (Poaceae) em uma área de Caatinga em Caruaru, Pernambuco. Revista Brasileira de Biociências, vol. 5 , pp. $858-860$.

ANDRADE-LIMA, D., 1981. The Caatinga dominium. Brazilian Journal of Botany, vol. 4, pp. 149-153.
ARAÚJO, E.L., CASTRO, C.C. and ALBUQUERQUE, U.P., 2007. Dynamics of Brazilian Caatinga: a review concerning the plants, environment and people. Functional Ecology and Communities, vol. 1, pp. 15-28.

ARAÚJO, E.L., SILVA, K.A., FERRAZ, E.M.N., SAMPAIO, E.V.S.B. and SILVA, S.I., 2005. Diversidade de herbáceas em microhabitats rochoso, plano e ciliar em uma área de Caatinga, Caruaru - PE. Acta Botanica Brasílica, vol. 19, no. 2, pp. 285-294. http://dx.doi.org/10.1590/S0102-33062005000200011.

AUGUSTINE, D.J., 2003. Spatial heterogeneity in the herbaceous layer of a semi-arid savanna ecosystem. Plant Ecology, vol. 167, no. 2, pp. 319-332. http://dx.doi.org/10.1023/A:1023927512590.

BAETEN, L., JACQUEMYN, H., CALSTER, H.V., BEEK, E.V., DEVLAEMINCK, R., VERHEYEN, K. and HERMY, M., 2009. Low recruitment across life stages partly accounts for the slow colonization of forest herbs. Journal of Ecology, vol. 97, no. 1, pp. 109-117. http://dx.doi.org/10.1111/j.1365-2745.2008.01455.x.

CONDIT, R., HUBBELL, S. and FOSTER, R.B., 1996. Changes in tree species abundance in a neotropical forest: impact of climate change. Journal of Tropical Ecology, vol. 12, no. 2, pp. 231-256. http://dx.doi.org/10.1017/S0266467400009433.

FLORES-TORRES, A. and MONTAÑA, C., 2012. Recruiting mechanisms of Cylindropuntia leptocaulis (Cactaceae) in the Southern Chihuahuan Desert. Journal of Arid Environments, vol. 84, pp. 63-70. http://dx.doi.org/10.1016/j.jaridenv.2012.04.006.

FORBIS, T.A., LARMORE, J. and ADDIS, E., 2004. Temporal patterns in seedling establishment on pocket gopher disturbances. Oecologia, vol. 138, no. 1, pp. 112-121. http://dx.doi.org/10.1007/ s00442-003-1404-3. PMid:14557865.

GARCÍA-CHÁVES, J.H., MONTAÑA, C., PERRONI, Y., SOSA, V.J. and GARCÍA-LICONA, J.B., 2014. The relative importance of solar radiation and soil origin in cactos seedling survivorship at two spatial scales: plant association and microhabitat. Journal of Vegetation Science, vol. 25, no. 3, pp. 668-680. http://dx.doi. org/10.1111/jvs.12139.

GUSTAFSSON, C. and EHRLÉN, J., 2003. Effects of intraspecific and interspecific density on the demography of a perennial herb, Sanicula europaea. Oikos, vol. 100, no. 2, pp. 317-324. http:// dx.doi.org/10.1034/j.1600-0706.2003.11493.x.

KOLB, A., LEIMU, R. and EHRLÉN, J., 2007. Environmental context influences the outcome of a plant-seed predator interaction. Oikos, vol. 116, pp. 864-872.

LEGER, E.A., GOERGEN, E.M. and FORBIS DE QUEIROZ, T., 2014. Can native annual forbs reduce Bromus tectorum biomass and indirectly facilitate establishment of a native perennial grass? Journal of Arid Environments, vol. 102, pp. 9-16. http://dx.doi. org/10.1016/j.jaridenv.2013.10.015.

LIMA, E.M., ARAÚJO, E.L., FERRAZ, E.M.N., SAMPAIO, E.V.S.B., SILVA, K.A. and PIMENTEL, R.M.M., 2007. Fenologia e dinâmica de duas populações herbáceas da Caatinga. Revista de Geografia, vol. 24, pp. 124-141.

MENEZES, R.S.C., SAMPAIO, E.V.S.B., GIONGO, V. and PÉREZ-MARIN, A.M., 2012. Biogeochemical cycling in terrestrial ecosystems of the Caatinga Biome. Brazilian Journal of Biology = Revista Brasileira de Biologia, vol. 72, no. 3, suppl., pp. 643653. http://dx.doi.org/10.1590/S1519-69842012000400004. PMid:23011295.

MILLER, A. and DUNCAN, R., 2003. Extrinsic and intrinsic controls on the distribution of the critically endangered cress, 
Ischnocarpus exilis (Brassicaceae). Biological Conservation, vol. 110, no. 1, pp. 153-160. http://dx.doi.org/10.1016/S00063207(02)00192-1.

MORI, A.S., SILVA, L.A.M. and LISBOA, G., 1989. Manual de manejo do herbário fanerogâmico. Ilhéus: Centro de Pesquisa do Cacau.

NIPPERT, J.B., KNAPP, A.K. and BRIGGS, J.M., 2006. Intraannual rainfall variability and grassland productivity: can the past predict the future? Plant Ecology, vol. 184, no. 1, pp. 65-74. http://dx.doi.org/10.1007/s11258-005-9052-9.

NORDBAKKEN, J.F., RYDGREN, K. and OKLAND, R.H., 2004. Demography and population dynamics of Drosera anglica and D. rotundifolia. Journal of Ecology, vol. 92, no. 1, pp. 110-121. http://dx.doi.org/10.1046/j.0022-0477.2004.00839.x.

PINO, J., PICÓ, F.X. and ROA, E., 2007. Population dynamics of the rare plant Kosteletzkya pentacarpos (Malvaceae): a nine-year study. Botanical Journal, vol. 153, pp. 455-462.

PRICE, J.N. and MORGAN, J.W., 2007. Vegetation dynamics following resource manipulation in herb-rich woodland. Plant Ecology, vol. 188, no. 1, pp. 29-37. http://dx.doi.org/10.1007/ s11258-006-9145-0.

REIS, A.M., ARAÚJO, E.L., FERRAZ, E.M.N. and MOURA, A.N., 2006. Inter-annual variations in the floristic and population structure of an herbaceous community of "Caatinga" vegetation in Pernambuco, Brazil. Brazilian Journal of Botany, vol. 29, no. 3, pp. 497-508. http://dx.doi.org/10.1590/S0100-84042006000300017.

SALO, L.F., 2004. Population dynamics of red brome (Bromus madritensis subsp. rubens): times for concern, opportunities for management. Journal of Arid Environments, vol. 57, no. 3, pp. 291-296. http://dx.doi.org/10.1016/S0140-1963(03)00110-1.

SAMPAIO, E.V.S.B., 1995. Overview of the Brazilian Caatinga. In: S. BULLOCK, H.A. MOONEY and E. MEDINA. Seasonally dry tropical forests. Cambridge: Cambridge University Press, pp. 35-58.

SANTOS, D.M., SILVA, K.A., ALBUQUERQUE, U.P. and SANTOS, J.M.F.F., 2013a. Can spatial variation and inter-annual variation in precipitation explain the seed density and species richness of the germinable soil seed bank in a tropical dry forestin north-eastern Brazil? Flora, vol. 208, no. 7, pp. 445-452. http:// dx.doi.org/10.1016/j.flora.2013.07.006.

SANTOS, J.M.F.F., SANTOS, D.M., LOPES, C.G.R., SILVA, K.A., SAMPAIO, E.V. and ARAÚJO, E.L., 2013b. Natural regeneration of the herbaceous community in a semiarid region in Northeastern Brazil. Environmental Monitoring and Assessment, vol. 185, no. 10, pp. 8287-8302. http://dx.doi.org/10.1007/s10661013-3173-8. PMid:23572402.

SANTOS, J.M.F.F., SANTOS, D.M., SILVA, K.A., ANDRADE, J.R., LIMA, E.N. and ARAÚJO, E.L., 2012. Influência da precipitação e de microhabitats na dinâmica de duas espécies de monocotiledôneas herbáceas em uma região semiárida no Nordeste do Brasil. In: A.C.A. EL-DEIR, G.J.B. MOURA and E.L. ARAÚJO, eds. Ecologia e conservação de ecossistemas no nordeste do Brasil. Recife: Nupeea, pp. 105-126.

SILVA, K.A., ARAÚJO, E.L. and FERRAZ, E.M.N., 2009. Estudo florístico do componente herbáceo e relação com solos em áreas de Caatinga do embasamento cristalino e bacia sedimentar, Petrolândia-PE. Acta Botanica Brasílica, vol. 23, no. 1, pp. 100-110. http://dx.doi.org/10.1590/S0102-33062009000100013.

SILVA, K.A., LIMA, E.M., SANTOS, J.M.F.F., ANDRADE, J.R., SANTOS, D.M., SAMPAIO, E.V.S.B. and ARAÚJO, E.L., 2008. Dinâmica de gramíneas em uma área de Caatinga de Pernambuco-Brasil. In: A.N. MOURA, E.L. ARAÚJO and U.P. ALBUQUERQUE. Biodiversidade, potencial econômico e processos eco-fisiológicos em ecossistemas nordestinos. Recife: Comunigraf, pp. 105-129.

SILVA, K.A., SANTOS, D.M., SANTOS, J.M.F.F. and ALBUQUERQUE, U.P., 2013. Spatio-temporal variation in a seed bank of a semi-arid region in northeastern Brazil. Acta Oecologica, vol. 46, pp. 25-32. http://dx.doi.org/10.1016/j.actao.2012.10.008.

SILVA, R.C.S., SANTOS, J.M.F.F., SANTOS, D.M., ANDRADE, J.R., PIMENTEL, R.M.M. and ARAUJO, E.L., 2011. Dinâmica de Delilia biflora kuntze sob a influência da sazonalidade climática e diferentes status de conservação em uma floresta seca do Brasil. Revista de Geografia, vol. 28, no. 2, pp. 132-148.

SLETVOLD, N., 2005. Density-dependent growth and survival in a natural population of the facultative biennial Digitalis purpurea. Journal of Ecology, vol. 93, no. 4, pp. 727-736. http://dx.doi. org/10.1111/j.1365-2745.2005.01008.x.

SOUZA, J.T., FERRAZ, E.M.N., ALBUQUERQUE, U.P. and ARAÚJO, E.L., 2014. Does proximity to a mature forest contribute to the seed rain and recovery of an abandoned agriculture area in a semiarid climate? Plant Biology, vol. 16, no. 4, pp. 748-756. http://dx.doi.org/10.1111/plb.12120. PMid:25068159.

SUZUKI, Z.O., KUDOH, H. and KACHI, N., 2003. Spatial and temporal variations in mortality of the biennial plant, Lysimachia rubida: effects of intraspecific competition and environmental heterogeneity. Journal of Ecology, vol. 91, no. 1, pp. 114-125. http://dx.doi.org/10.1046/j.1365-2745.2003.00745.x.

SWAINE, M.D. and LIEBERMAN, D., 1987. Note on the calculation of mortality rates. Journal of Tropical Ecology, vol. 3, pp. 2-3.

THOMSON, D., 2005. Measuring the effects of invasive species on the demography of a rare endemic plant. Biological Invasions, vol. 7, no. 4, pp. 615-624. http://dx.doi.org/10.1007/ s10530-004-5853-3.

VEGA, E. and MONTAÑA, C., 2004. Spatio-temporal variation in the demography of a bunch grass in a patchy semiarid environment. Plant Ecology, vol. 175, no. 1, pp. 107-120. http:// dx.doi.org/10.1023/B:VEGE.0000048094.21994.74.

VOLIS, S., MENDLINGER, S. and WARD, D., 2004. Demography and role of the seed bank in Mediterranean and desert populations of wild barley. Basic and Applied Ecology, vol. 5, no. 1, pp. 5364. http://dx.doi.org/10.1078/1439-1791-00192.

WANG, R.Z., 2005. Demographic variation and biomass allocation of Agropyron cristatum grown on steppe and dune sites in the Hunshandake Desert, North China. Grass and Forage Science, vol. 60 , no. 1, pp. 99-102. http://dx.doi.org/10.1111/j.13652494.2005.00445.x.

ZAR, J.H., 1996. Bioestatistical analysis. 3rd ed. New Jersey: Prentice Hall. 